\begin{abstract}
Виктор Трајановски (Северна Македонија) Институт за етнологија и антропологија Природно-математички факултет Универзитет „Св. Кирил и Методиј“ - Скопје Е-маил: trajanovskiv@yahoo.com
\end{abstract}

\title{
БЕКТАШКИОТ ТАРИКАТ ВО МАКЕДОНИЈА ЗА ВРЕМЕ НА СОЦИЈАЛИЗМОТ
}

\begin{abstract}
Апстракт: Предложениот труд има за цел да му понуди на читателот одредени податоци за најзначајните карактеристики и специфичности на бекташкиот дервишки ред во Македонија за време на социјалистичкиот период. Опфатени се одредени политички одлуки, но и општествени појави и процеси што директно ќе влијаат врз (не)егзистирањето на одредени бекташки теќиња, но и врз текот на бекташкиот живот воопшто.
\end{abstract}

Клучни зборови: бекташки тарикат, доктрина, социјалистички период, „Договор за слободна емиграција“, „Петгодишен план“, национализација.

Социјализмот како идеологија и како основа за општествено уредување на одреден број земји во светот постојано е во интересот на истражувачката јавност, особено по неговиот пад и промените што се случија во почетокот на 1990-тите години. Голем број од истражувачите што решиле да се позанимаваат со социјализмот својот фокус на интерес го насочиле кон анализирање на одредени верски прашања. Овој труд е само еден од многуте што разработуваат одредени верски проблематики за време на социјализмот, односно целта на трудот е да им понуди на читателите што е можно подетални податоци за најзначајните карактеристики и специфичности на бекташкиот дервишки ред во Македонија за време на социјалистичкиот период.

На самиот почеток на овој труд би сакал читателот во кратки црти да го запознам со основните постулати на бекташкиот тарикат, односно на бекташкиот дервишки ред како што мнозина милуваат да го наречат, со цел читателот да има појасна слика за овој тарикат.

Бекташкиот дервишки ред припаѓa на езотеричната страна на исламот, позната како суфизам или тасавуф, чија основна цел е внатрешно 
издигнување и остварување на Божјото единство, односно начин на живот насочен кон соединување со Апсолутната Вистина, т.е. со Бог.

Една од главните предиспозиции што треба да ја поседува поединецот што решил да појде по патот на суфизмот е припадноста кон исламот, бидејќи методите на суфизмот се неефективни без оваа верска припадност (види: Што е тоа Суфизам: http://www.islamska-zaednica.com/forum/ topic/945-што-е-тоа-суфизам/).

Бекташкиот дервишки ред се поврзува со името на Хаџи Бекташ Вели, кој се смета за основач и духовен лидер на овој ред, според кого овој тарикат го носи името. Хаџи Бекташ Вели потекнувал од гратчето Нишапур (Nishabur) во персиската провинција Хорасан, денешен Иран, место што се смета за лулка на суфизмот. Дошол во Мала Азија во 13 век, се населил во соседство на Киршехир, во селото Сулуџа Карахојук (тур. Suluca Karahöyük), кое подоцна го добило неговото име Хаџи Бекташ (Birge 1937: 50). Таму го оформил суфискиот центар, главното теќе на бекташите, познато како „Пир Еви“ (тур. Pir Evi), од каде што подоцна се испраќани мисионери да го шират бекташкиот пат низ цела Анадолија и на Балканот.

Поради нивната езотеричност, не може точно да се утврди почетокот на постоењето на овој дервишки ред. Но, сепак, етаблирањето на овој ред е тесно поврзано со Бал’м Султан (1473 - 1516), кој е одговорен за утврдување на постојната структура на бекташкиот ред. Тој спровел голем број реформи, имал контрола над сѐ и ги унифицирал бекташките правила. Како резултат на оваа трансформација, Бал'м Султан се смета за вториот светец и вториот основач (тур. İkinci Pir, перс. Piri Sani) (Birge 1937: 56).

Што се однесува до суштината на учењето на бекташите, догмите или темелните точки на верското учење, бекташкиот тарикат се темели на уникатно и препознатливо читање на Куранот и следење на светиот пат на Хунќар Хаџи Бекташ Вели, кого бекташите го сметаат за личност што добро го сфатила и го објаснила езотеричното во Куранот; следење на учењата и практиките на пратеникот Мухамед и хазрети Али; почит кон семејството на пратеникот Мухамед - „ехли-бејтот“, почит кон 12-те имами и 14-те безгрешни жртви, т.н. масуми (masum-i pak), деца на имамите; потоа, верување во евлии, т.е. светци; следење на доктрината на четирите порти, која не може да се замисли без ликот на муршидот или учителот, кој го знае најдобро патот што води до севишниот Алах, односно Хак, односно Вистината (види: Ćehajić 1986: 162; The Path to Insight: http://bektashiorder. com/the-path-to-insight).

Она што ги одвојува бекташите од конвенционалниот ислам е непридржувањето до некои шеријатски правила. Па така, бекташите не постат за време на месецот рамазан, не ја извршуваат петдневната молитва или намаз, потоа, употребуваат дем или алкохол при нивните обреди, но и во секојдневното живеење, аџилакот не го сметаат за задолжителен пропис, па неретко ќе речат: нашиот аџилак не е да одиме и да се поклониме во Мека, туку да влеземе во срцето на нашите муршиди. 
Еден од најзначајните верски настани што ги одбележуваат бекташите е празникот Невруз или, како што некои го нарекуваат, Султан Невруз, кога се одбележува роденденот на имамот Али, кој паѓа на 21 март, што се совпаѓa со денот на започнувањето на пролетта. Вториот значаен верски настан за бекташите е одбележувањето на Денот на ашуре. Тоа е траурен празник и се одбележува во спомен на мачеништвото и смртта на имамот Хусеин, кој бил измачуван и убиен во местото Кербела, денешен Ирак, од страна на приврзаниците на умајадскиот калиф Језид (види: Конеска 2008: 423; Јордановска 2014).

За бекташите свет храм претставува теќето. Тоа е место каде што бекташите ги извршуваат своите верски обреди и церемонии. Теќето претставува молитвен дом, место за контемплација и трагање по Реалноста. Во теќето живеат или престојуваат следбениците на тарикатот (муриди, мухипи), кои под материјална и смисловна контрола на еден одреден старешина (муршид) настојуваат да ги разубават нивниот морал и етика врз основа на исламските суфиски начела (Kara 1999: 50, цитирано во: Изети 2008).

Водејќи се од доктрината за еднаквост на сите човечки суштества пред Бога, бекташкиот тарикат е единствен што ги интегрира жените давајќи им еднаков третман со мажите, како учесници во духовните обреди, но и како партнери во секојдневниот живот. Вклученоста и учеството на жената во верските обреди заедно со мажите претставуваат една од позначајните карактеристики на овој дервишки ред, што го прави овој дервишки ред уникатен.

Политиката за ширење на исламската култура низ целиот Балкан била успешно спроведена и во Македонија. Иако исламот во Македонија се распространил, главно, како сунитски, заедно со него дошле и разни учења, движења и институции, т.е. разни дервишки редови со најразлична идеолошко-верска ориентација, од најконзервативна до најреволуционерна (Стојановски 1998: 393).

Судејќи според теќињата и турбињата што може да се сретнат низ територијата на Македонија, слободно може да се каже дека бекташкиот дервишки ред бил еден од најраспространетите тарикати во Македонија, кој оставил силен белег во духовниот живот во Македонија и на Балканот. Тој е еден од неколкуте тарикати што денес може да се пофали со присуство на голем број активни теќиња во разни делови на Балканот, особено во Македонија, Албанија и на Косово, и покрај репресиите што ги доживеал во различни периоди од неговото дејствување.

Најстариот објавен пишан документ што сведочи за присуството на бакташите во Македонија датира од 16 век. Се работи за запис од 1544 г., а се однесува на теќето Х'д’р-баба (Петровски 1994: 84; Стојановски 1979: 55) во Македонски Брод, кое се смета за едно од најстарите бекташки светилишта во Македонија (види: Hasluck 1929: 523-525). 
Од истиот период, од 16 век, се претпоставува дека потекнуваат Дикмен-баба теќето во Канатларци, како и теќето Харабати-баба, познато уште и како Серсем Али-баба теќе во Тетово. Денес, покрај овие гореспоменати теќиња, во Македонија е активно уште и теќето Х’д’р-баба во Кичево.

Во минатото на територијата на Македонија биле присутни повеќе бекташки теќиња во различни градови и населени места. Па така, бекташки теќиња имало во следниве места: во Битола - теќето на Хусаинбаба; во Скопје - Мустафа-баба и Сулејман-баба; во близина на станицата на Александрово, помеѓу Куманово и Скопје - мало теќе со гроб на Караџа Ахмед; во Струмица, поточно во струмичката област - Исмаил-баба (Izeti 2001: 163); теќињата Џарар-баба и Којун-баба во Тетовско; теќето на Џафербаба во Гостивар (Изети 2008: 196); во Штип на Хамза-баба; во Велес на Хаџе-баба; во Дебар на Али-баба. Потоа, во село Каратманово било теќето на Камбер-баба, во село Џумали - Јусуф-деде, во село Татарли - Илми-деде и др.

Кога станува збор за бекташкиот тарикат во социјалистичкиот период, невозможно е хируршки прецизно да се отстрани и да се согледа како засебна целина исклучиво во Македонија. Одредени процеси и појави што се случувале во рамките на Југославија имале еднаква важност и примена на ниво на сите републики, односно одредени закони, одлуки и решенија што се носеле имале еднаква примена врз сите жители на СФР Југославија. Исто така, одредени бекташки старешини имале полн легитимитет да управуваат со повеќе теќиња распространети ширум СФР Југославија.

Во периодот од 1945 до 1990 година, на просторот на поранешна Југославија се издвојувало бекташкото теќе во Ѓаковица под раководство на баба К̆азим Бакали, кој станал старешина на редот на целото балканско подрачје, Македонија, Косово, Албанија. Ова теќе одиграло значајна улога во зачувувањето на бекташката традиција на овие простори (Ćehajić 1986: 172; Конеска 2009: 234), така што заслужено можеме да го наречеме бекташкиот бисер за време на социјализмот на Балканот. Голем број дервиши од различни теќиња, особено во Македонија, во лидерската функција на баби биле назначени токму од ова теќе, односно од поглаварот на ова теќе, надалеку почитуваниот старешина Ќазим Бакали.

Казим Бакали... Тој беше ілавен во СФР Јуіославија... за бекӣашиийе $e^{1}$.

...Се рачуна како ценйар за бекйашииие... Џаково, Џаковица во

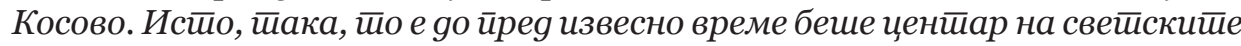
бекйашии. Дур Албанија не беше оишворена земја ${ }^{2}$.

1 Сопствени теренски истражувања, 2013 година, јужен дел на Македонија, дервиш во бекташкиот тарикат на 50-годишна возраст, Турчин.

2 Сопствено теренско истражување во Охрид, 2018 година. Соговорник Ејуп Салих, роден на 22.9.1950 година во Охрид, муслиман, Турчин. 
Наспроти ваквата позитивна дејност што ја вршело ова теќе во Ѓаковица и баба Ќазим Бакали, за одбележување во социјалистичкиот период е „Договорот за слободна емиграција“, склучен помеѓу ФНР Југославија и Република Турција во 50-тите години на 20 век, познат уште и како „Џентлменски договор“, со кој се предвидува иселување на турското население од ФНР Југославија во Република Турција. Овој договор бил судбоносен за тарикатскиот живот и теќињата во Македонија. Тарикатите во Македонија најмногу биле изложени на иселување на муслиманската популација во Турција. До шеесеттите години на 20 век, многу теќиња на подрачјето на Македонија, кои некогаш ги населувале Турци, се опустошени како резултат на преместувањето на населението (Трајановски 2018: 35-36).

И йосле йоа нашиве се ирреgомислиле ќе се врайай Турција, ког̄а gошол веќе СФРЈ. Османлииие изйубиле овgека, завршиле. Пеитсио йейшеесей гооини колку држеле овgека и Макеgонија. Веќе ког̄а изіуубиле, ӣa gошол кралска Југ̄ославија, йа дошол не знам срйска Јуїославија, каква Јуіославија било, йа Тийо ни донесе СФРЈ, Социјалистичка Феgерайивна Рейублика Југ̆ославија. И се онаgувай, доі̄овор се йрай, кој сака може gа си оgи Турција. Па gа се врайай во рояниой крај... Не, йоа самоволно, немало ириииисок, а се йлашеле... ${ }^{3}$

Еден еклатантен пример што ја отсликува ваквата состојба претставува оној од село Горно Врановци, Велешко. Во овој период има масовно иселување на врановчани во Турција. Жителите на целото село, со исклучок на една фамилија, се иселуваат во Турција, што ќе биде фатално за бекташкиот живот во Горно Врановци.

Анета Светиева, при нејзините теренски истражувања во ова село направени во 1999 година, во рамките на проектот „Мултикултурните и етничките особености на четири велешки села“, наишла на неколку гробови на чии споменици, според неа, имало бекташки обележја, за потоа, таквиот нејзин заклучок да го потврди нејзиниот соговорник, единствениот староседелец што му се спротивставил на феноменот наречен миграција и останал да живее во Горно Врановци. Податоците добиени од нејзиното истражување ќе бидат изнесени во нејзиниот труд со наслов „Селата Мелница и Горно Врановци во Велешко“ каде што авторката вели: „Сунитскиот ислам изгледа немал подлабоки корени, за што зборуваат остатоците од четирите дервишки гробови кои народот ги нарекува 'теќиња', потоа симболите на камените надгробни обележја, а до скоро постоеле и остатоци од т.н. 'дервишка џамија'. Според информациите од теренот, во селото имало припадници на дервишките редови 'бекташи' и 'рифаи'. Масовното иселување на Врановчани во Турција започнало околу 50-тите години на 20. век. Денес во селото има само едно семејство од староседелците. Денешните жители се главно Албанци од Косово и соседните велешки албански села Горно и Долно Јаболчишта кои се доселувале паралелено со иселувањето на Врановчани“" (Светиева: http://www.ethnologs-dep.org/VELES/indexV.htm).

3 Сопствени теренски истражувања, 2019 година, јужен дел на Македонија, дервиш во бекташкиот тарикат на 60-годишна возраст, Турчин. 
По добиените податоци од Анета Светиева, но и од текстот што го напишала, се обидов да дознам одредени податоци за некогашните бекташи од ова населено место преку моите познанства со лица што се потомци на иселени врановчани во Турција. По повеќе неуспешни обиди и контакти, на крајот наидов на Мухарем Аксу, кој ги потврди ваквите сознанија на Анета Светиева, но, овој пат со конкретни имиња на некои од фамилиите, но и на евлиите, т.е. светците.

Инаку Мухарем Аксу (старо презиме Османоски) е роден во 1945 година во Горно Врановци и десет години, односно до 1955 година, живеел таму пред неговата фамилија да се исели во Измир, Република Турција.

Османоски, за ииурско време Осман, йосле Османовци. Оg мајка ми иуцинско иррезиме Фазлоска. Деgойо ми беше 1944 іолина со вујко ми, беа

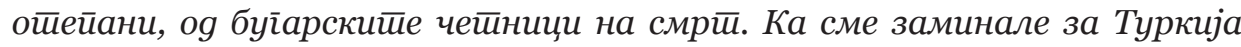

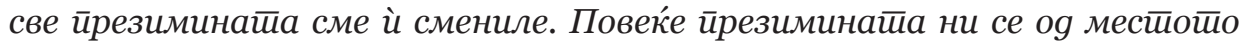
Врановци, на йример: Бела Воgа - Аксу, Далі̄а (gолі̄а) ливаgа - Узунбаир, Црн камен - Карайаш и йамо найамо

Во врска со бекташите и бекташкиот тарикат во неговото родно место или мемлекетот, Мухарем со мене го сподели следново: Да, биле бекӣаши во Врановци. Имале gервиши бекишаши и руфаи и имале меламии. Имаше фамилии се зовеле Суруцијовци, йие биле бекишаши. Имаме во Врановци Рамаgан-gеgе, ииој бил бекииашки gеgе. Гробой му је іоре во осој. Имай во

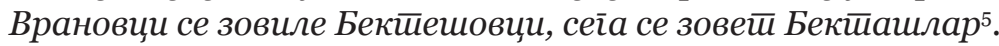

Покрај врановчани, исто така како последица од склучувањето на „Договорот за слободна емиграција“ помеѓу ФНР Југославија и Република Турција, голем број од населението во Овчеполието, поточно од населените места Дорфулија, Каратманово, Милино и др., масовно ги напуштило родните огништа и заминало за Турција, а со тоа згаснал и животниот век на бекташкиот тарикат во овие места.

Единствената бекташка фамилија во село Дорфулија што му се спротивставила на масовното иселување во Турција и останала да живее во родното место е фамилијата Шерифови. Највозрасниот член од ова семејство Ајет Шерифов, заедно со својата сопруга, братот и снаата, бил воведен во бекашкиот тарикат од прочуениот муршид на овие простори во тоа време - халифе-баба К̆азим Бакали во далечната 1962 година, додека, пак, неговиот татко Караман за мухип или полноправен член во бекташкиот тарикат го назначува Амза-баба.

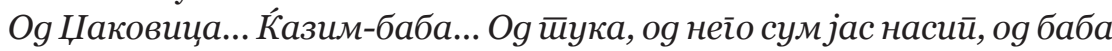

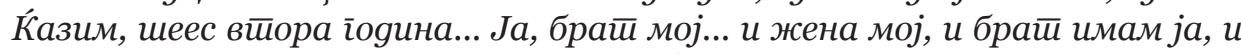
йие умреа, ушие е и јеніе (снаа)... не иееке, gома... со муабей... Ние викаме

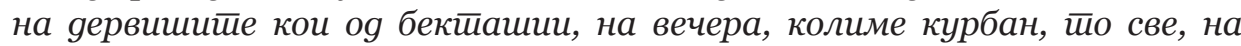

4 Сопствени истражувања. Соговорник Мухарем Аксу (Османоски), роден во 1945 година во Горно Врановци. Денес живее во Измир, Република Турција.

5 Сопствени истражувања. Соговорник Мухарем Аксу (Османоски), роден во 1945 година во Горно Врановци. Денес живее во Измир, Република Турција. 


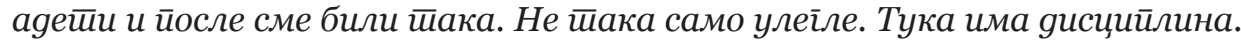
Бекӣаши мнойу јак gисцийлина... Тайко ми земал оg Амза-бабаб.

Наше село имаше ииог̆ај беше, цело Турци. Имаше десейина,

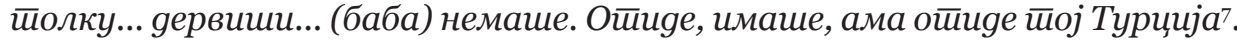

Последниот бекташки старешина во Дорфулија бил Вели-баба. Тој заедно со својата фамилија во педесеттите години се иселува во Турција.

Вели-баба... Он је, йука е, иееес сеgма, иееес осма... Вияи, йој баба не беше, ӣосле баба бияе, ко ӣоминаа Ќазим-баба, он е йосле баба биgен... ама више немаше, баба йука не gоjge 8 .

Ваквата експанзија на иселување во Турција негативно ќе се одрази врз бројот на турското население во селото, а уште повеќе овој процес на иселување ќе биде поразителен за бекташите и бекташкиот живот во Дорфулија и околните села.

Найреg имаше шеесе... йочнаа йеес йрейа gо шеестиа. Имаше сеgамgесе фамилии йовише овgе бекйаши... Виgи наша фамилија осйана Шерифови, осииана Мислим-айа (Müslüт-аgа), осйана и Нијази-беіова... Само осиианавме йри фамилии... Денес сме само ја и моја жена, нема село oвge ${ }^{9}$.

Оние што се преселиле во Турција ќе го продолжат бекташкиот тарикат во новата средина. Со текот на времето некои од нив и духовно ќе созреат до степен на баби.

Og наше село има ирри баба Турција, Измир, оg наше село..

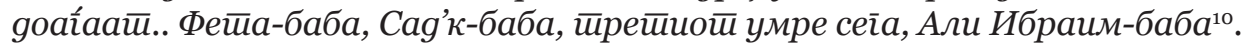

Што се однесува до другите села во блиската околина на Дорфулија, моите соговорници ми напоменаа дека во минатото бекташи можело да се сретнат во селата: Татарли (Милино) каде што се наоѓa турбето на Илмидеде и во Каратманово во кое постои гробот на Камбер-баба.

Дел од оние бекташи што ја избегнале оваа „слободна емиграција“ и кои успеале да останат во Македонија и да ги зачуваат бекташките светилишта се соочиле со комунистичката власт, со нејзиниот поглед кон верското прашање, но и со одредени политички одлуки што директно влијаеле врз (не)функционирањето на одредени теќиња.

„Комунистичката партија во однос на т.н. верско прашање барем декларативно прокламирала дека теистичкиот или атеистичкиот поглед

6 Сопствени теренски истражувања, 2018 година, Дорфулија. Соговорник Ајет Шерифов, мухип во бекташкиот тарикат на 76-годишна возраст.

7 Сопствени теренски истражувања, 2018 година, Дорфулија. Соговорник Ајет Шерифов, мухип во бекташкиот тарикат на 76-годишна возраст.

8 Сопствени теренски истражувања, 2018 година, Дорфулија. Соговорник Ајет Шерифов, мухип во бекташкиот тарикат на 76-годишна возраст.

9 Сопствени теренски истражувања, 2018 година, Дорфулија. Соговорник Ајет Шерифов, мухип во бекташкиот тарикат на 76-годишна возраст.

10 Сопствени теренски истражувања, 2018 година, Дорфулија. Соговорник Ајет Шерифов, мухип во бекташкиот тарикат на 76-годишна возраст. 
на светот е приватно право или лична слобода на секој поединец. Притоа во август 1945 година Министерскиот совет на Демократска Федеративна Југославија донел уредба за основање на државна комисија за верски прашања“ (Илиевски 2011: 35). „Во состав на републичките влади биле формирани републички комисии за верски прашања кои требало да работат според упатствата на државната комисија. Верската комисија во Македонија била формирана во 1945 година и работела под претседателство на Епаминонда Поп Андонов. Задачата на оваа комисија била да ја проучи состојбата на верски план и да одржува контакти со православната црква како и со муслиманската и еврејската верска заедница во Македонија“ (Илиевски 2011: 35).

Од моите соговорници, во однос на верската слобода за време на социјализмот, можев да слушнам порезервирани искази. Повеќето од нив кажуваа дека бекташите немале некакви посебни проблеми и притисоци од тогашната власт, но сепак не било сеедно доколку се открие дека одреден човек, особено ако бил член на партијата или вработен во државни органи, оди на богослужба или дека има видна улога или титула во верската организација, во конкретниов случај во бекташкиот тарикат.

Слушај вака, во ииийовскойо време?... Не, не ираеше ирроблеми... Не, не, ириииисок никаков не йраеше... како сейа е и йойаш исииойо беше... А вака имаше ириииисок... Og време никој нема иррекинайо. Никој, никој,

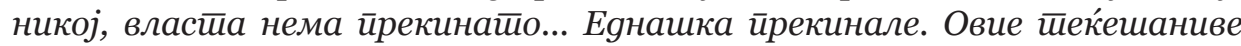
ирекинале меи́y себе ${ }^{11}$.

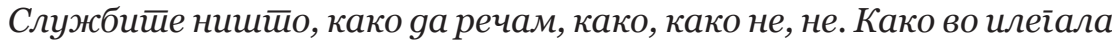

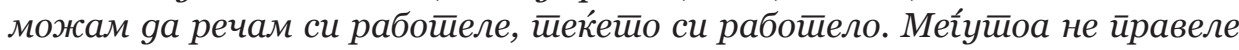
никакви йроблеми никому и си оgеле на бог̆ослужба, си се враќкле на

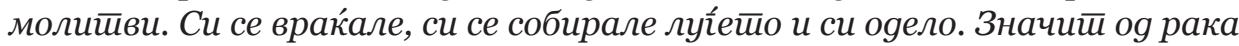

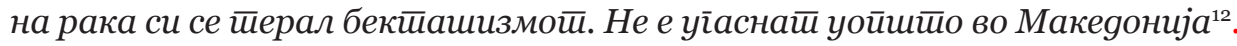

И покрај ваквата слика на умерен однос на комунистичката власт кон бекташите и нивните светилишта, во овој период се појавува една политичка одлука, односно е донесен Закон за национализација, кој ќе има негативен ефект врз одредени теќиња. Едно од бекташките теќиња што било жртва на ваквата одлука, кога локалните власти решаваат да го узурпираат и да го претворат во туристички објект, е Харабати-баба теќето во Тетово. Одредени делови од ова теќе во 70-тите години на 20 век биле претворени во хотел, ресторан и диско, со што на бекташките верници им било скратено правото на слободно исповедување на верата и пристапот до нивното вековно светилиште. Во овој период, поради пијаната изопаченост на бројни гости во хотелот, ресторанот и диското, дошло до сквернавење на надгробните споменици, при што биле уништени и се уринирало врз нив, а, исто така, бил опожарен главниот комплекс со турбињата, што предизвикало

11 Сопствени теренски истражувања, 2017 година, јужен дел на Македонија, мухип во бекташкиот тарикат на 70-годишна возраст, Турчин.

12 Сопствени теренски истражувања, 2019 година, западен дел на Македонија, баба во бекташкиот тарикат на 59-годишна возраст, Турчин. 
начителни штети на гробовите на многу светци погребани во нив. Извесен период во рамките на теќето бил сместен Музејот на тетовскиот крај. За време на овие прекини, бекташите ги извршувале духовните служби по куќите или во бекташките теќиња во другите градови.

Ама, ама во Тейово, во Тейово gа. Уїаснай је во Тейово. Знаейе зошиио? Зайо шийо со Законой за национализација, знаеме дека во илјаgа

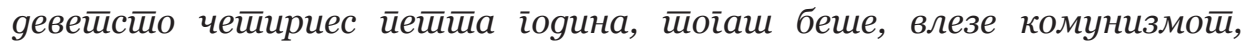

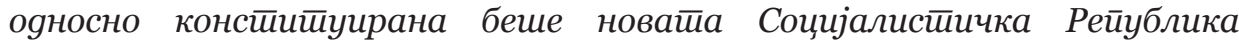

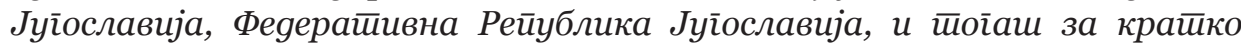
време се изврши национализација. Законо за национализација іо онесоја. То беше оgма, илјаgа gевейсйо и иееесей и шесйа, йеес и сеgма їоgина, gа.

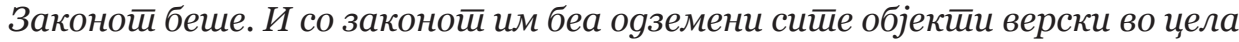

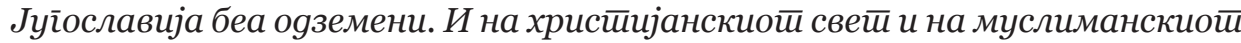
свеші... Теќешио йосле беше оgземено и йосле йоа, йосле неколку іодини

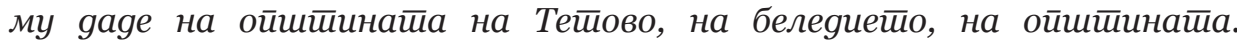

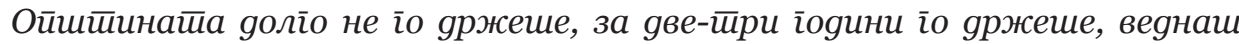

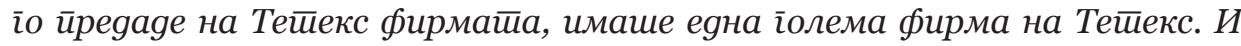

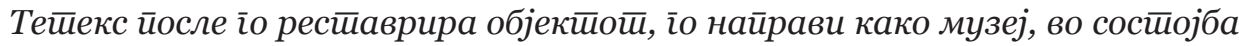
на музеј іо gонесе. Така gа, јайанийе йосебно іи оgвои, оние шиио се

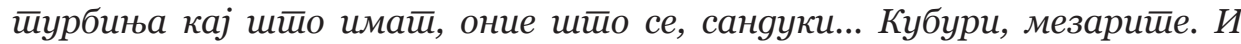
йоgели Арабайи-баба иееке йосебно. Го найрави иио, заірраgено, йосебно

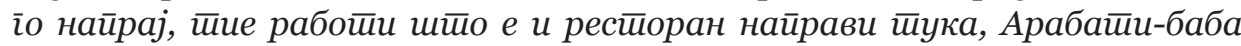
иеке́ рестиоран. Ког̆а сакайе gа оgиие во ишурбињейо со билей се оgеше, ио иррейвори во музеј... Е йака беше. Немаше тиог̆аш. Таму еркан немаше.

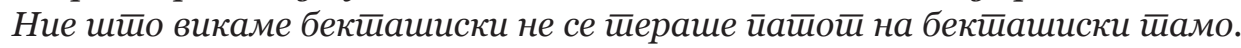
Немаше $^{13}$.

По распадот на Југославија и создавањето на независна Република Македонија во 1991 година, македонската влада не успеа да ги задоволи барањата за негово целосно, правно враќање на претходните сопственици, иако последните бекташки баби Тајар Гаши, а подоцна и баба Тахир Емини во еден дел од него повторно влегуваат при што започнала ревитализација на теќето Харабати-баба. Во меѓувреме Музејот на тетовскиот крај е иселен, а престанува и угостителската дејност и хотелското сместување.

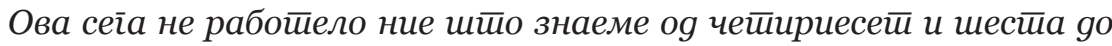

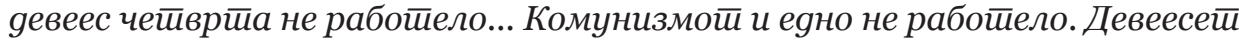

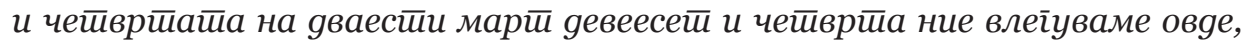
со баба Тајар влеїуваме. Влеїуваме на йри дена. Тајар Гаши. Влеїуваме на йри gена gа іо славиме Сулйан Невруз во йаа соба, во овие ирросйории. Зеgовме gозвола, йойај беше Ѓунер Исмаил беше министер за кулииура. Десей gена без јаgење, без ииење ово-оно. И осианавме и иродолжи gевеес чеивврииа іолина ${ }^{14}$.

13 Сопствени теренски истражувања, 2019 година, западен дел на Македонија, баба во бекташкиот тарикат на 60-годишна возраст, Турчин.

14 Сопствени теренски истражувања, 2018 година, западен дел на Македонија, дервиш во бекташкиот тарикат на 68-годишна возраст, Албанец. 
Едно од неколкуте бекташки теќиња што успеало да избега од канџите на комунистичката власт и да го продолжи животниот век е Хусеин-баба теќето во Битола. Ова теќе, според зацртаниот „Петгодишен план“ (Закон на Пейі̄oguшниоӣ ӣлан... 1947) за развиток на градот Битола, требало да биде целосно срушено. Но, благодарение на Хусеин Таипи, виден жител од село Асамати, Преспа, воедно мухип, т.е. полноправен член во бекташкиот тарикат, но пред сѐ партизан и симпатизер на Комунистичката партија (навистина една интересна комбинација), кој успева да ги разубеди локалните власти да го изземат ова теќе од петгодишниот план и да дозволат бекташите и понатаму да ги извршуваат своите верски обреди во ова за нив драгоцено светилиште, теќето продолжува со својата дејност.

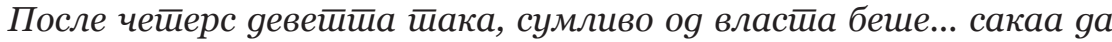

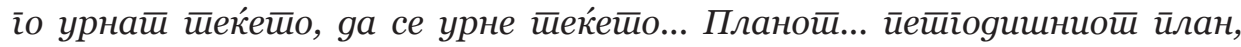

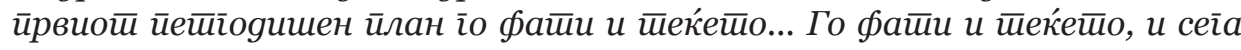

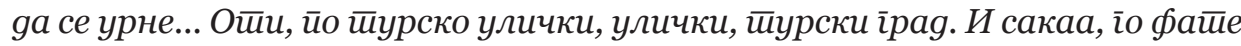

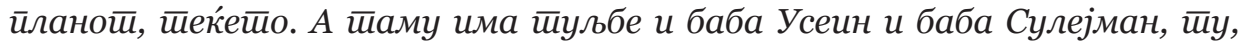

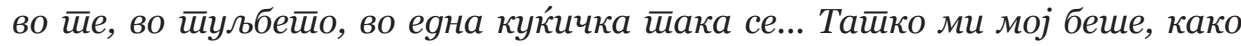

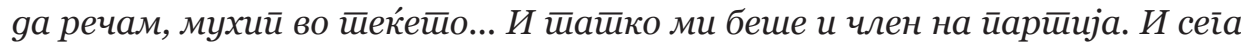

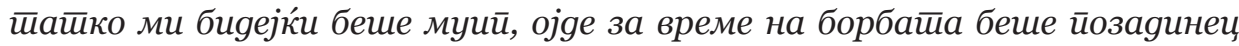

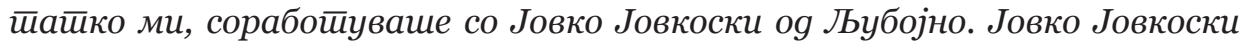

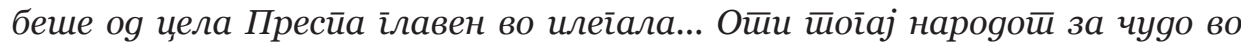

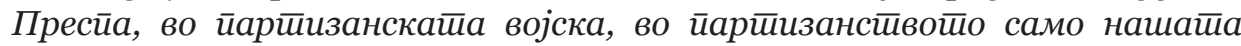

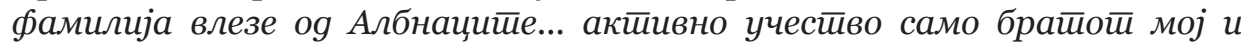

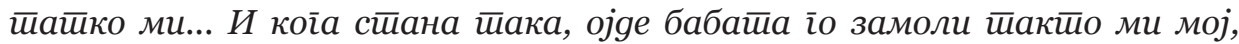

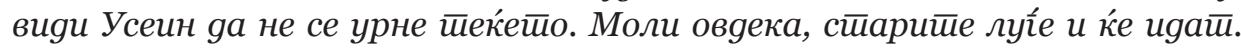

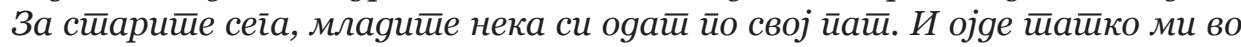

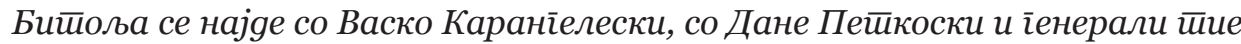
беа... И кај ииче челнийе во Бийоља шо беше брай ми со нив йарииизан...

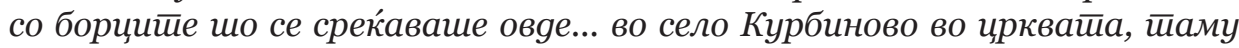
се среќкваше. Пошӣа ирренесуваше оg Албанија овgека, јас ја чийав

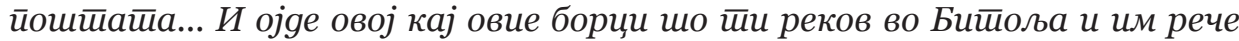

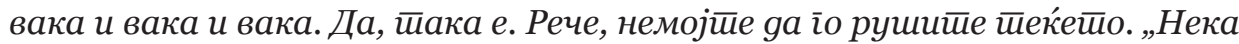

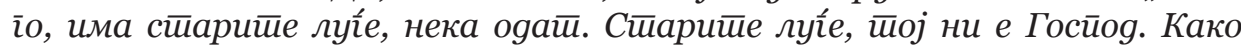
шйо се верници.“"И рекоа: „Не, ќе се руший сейне... ќе їо рушиме!“И вака

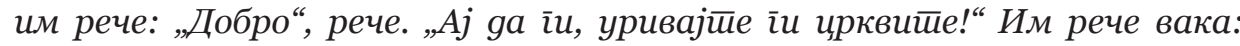

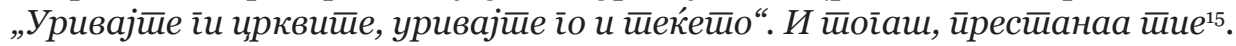

На тој начин Хусеин-баба теќето во Битола ја преживува ваквата закана од уништување, а најзаслужни за тоа, како што напоменав, се Таип Таипи и неговиот татко Хусеин Таипи од Асамати.

По овој настан, дали поради страв од комунистичката власт, теќето почнало да добива позатворена форма. Не било целосно затворено за верниците, но, на некој начин обредите, па и посетите се редуцирале и се одвивале во тајност.

15 Сопствени теренски истражувања, 2017 година, северен дел на Македонија, мухип во бекташкиот тарикат на 89-годишна возраст, Албанка. 
Денес Хусеин-баба теќето во Битола условно не функционира. Велам условно, бидејќи одредени сознанија до кои дојдов велат дека сепак во него е застапен бекташки живот, но се чува во најголема тајност. Причините за ваквата состојба му се познати единствено на поглаварот на ова теќе и на неговото најтесно окружување. А ние другите може само да нагаѓаме дали ваквата прикриеност е од политичка, верска, етничка или од некаква друга причина.

Во однос на светилиштето X'д’р-баба во Македонски Брод, за кое голем број бекташки верници сметаат дека е еден од најстарите бекташки храмови на територијата на Македонија, одредени интересни информации за социјалистичкиот период наоѓaме кај Елизабета Конеска, кои се базираат на нејзиното теренско истражување направено во Македонски Брод и Кичево. Во нив се вели дека по Втората светска војна светилиштето било прилично запоставено и постепено се руинирало, иако и понатаму било посетувано, особено од муслиманите бекташи. Еден од нејзините соговорници ја информирал дека бекташите од Канатларци, по кусата посета во турбето во кое немало услови за молитви, честопати ги примал во својата куќа, која е недалеку од турбето, каде што во најголемата просторија на вториот кат ги изведувале своите ритуали со молитви и пеење духовни песни (Конеска 2006: 165).

„Кон крајот на 70-тите или почетокот на 80-тите години на 20 век веројатно била покрената иницијатива за заштита и обновување на теќето, односно турбето. На претпоставената иницијатива надлежниот митрополит одговорил со акција за обновување на објектот. При тоа направен е записник за состојбата на црквата-турбе Свети Никола во текот на 1984 година во кој меѓу другото стои и дека црквата ја отклучила чуварката Христина Терзиоска, а во внатрешноста покрај светиот престол и икони имало и многу 'елементи од исламската вероисповед'. Подот делумно бил прекриен со овчи и јагнешки кожи, а насреде бил поставен 'импровизиран турски гроб‘ на кој богомолците имале оставено богати дарови. За гробот во записникот се наведува дека богомолците го почитувале како гроб на Св. Никола, т.е. Ајдар-баба. Тогаш дрвениот сандак на гробот, со валчест облик, направен од зелено обоени штици, кој бил централно поставен бил поместен за еден метар кон јужниот зид“ (Записник б.б. составен на ден 8.4.1984, цитирано во: Конеска 2006: 165). „Кон крајот на 80-тите години следувало обновување на објектот, при што бил поставен иконостас, а во текот на 1994 година објектот бил осветен како црква“ (Конеска 2006: 166).

Кога станува збор за бекташката заедница во Струга, можеме да констатираме дека таа денес за жал не постои. Можеби егзистираат одделни бекташи до кои тешко може да се дојде поради затворениот карактер на групата/фамилијата што во најголема тајност го следи бекташкиот тарикат. За разлика од ова, во социјалистичкиот период, некаде околку педесеттите години на 20 век, Струга била плодна средина за духовен развој на бекташите со кои раководел надалеку познатиот и почитуван Календер Усни Кемалбаба. Во отсуство на бекташко теќе во Струга, најчесто верските обреди се 
одржувале во куќата на Усни Ќемал-баба каде што имал адаптирано мејдан за потребите на тарикатот.

Токму за Усни Ќемал-баба информации од прва рака добив од мојата соговорничка Дидар Доко, која е внука од сестра на почитуваниот струшки баба Календер Усни К̈емал Сејран: Вујко ми мој Усни Ќемал-баба,

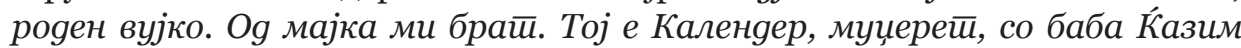
истио време се служени. Вујко ми умре со илјаgа девейсиио шеес иирейа іоgина со земјойресои... родени вујко ми е. Најзначајниой во Макеgонија, можgа и на Балканой. Календер е бияен, исӣо време іо ілеgале во Скойје,

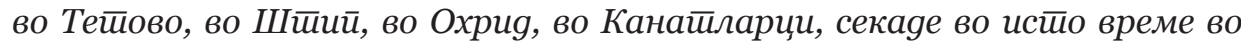
gванајс сайой...

Освен на нејзиниот вујко Усни Ќемал-баба, мојата соговорничка се досети на уште двајца бекташии во тоа време во Струга, Ајдар и Али Вишко: Ajgap Аио беше во Сйруг̆а бекйаш, онgе карши ойел Дрим, и Али Вишко. Мајка му оg Али Вишко и мајка ми моја се оg gве сесшири gеца. Порекло е оg Албанија. Бекӣашии се и ииие ${ }^{16}$.

Што се однесува до постоењето на бекташки теќиња во Струга,

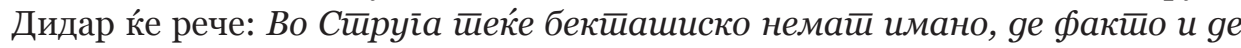
jуре, не, не ${ }^{17}$.

Миленко Филиповиќ, истражувајќи во 50-тите години на 20 век во Струмичко, дава одредени податоци за постоење на бекташи во селата: Бањско, Свидовица и Макриево (Мокриево) во областа Подгорје или Подгорија, под северните падини на Беласица. За селото Свидовица вели дека е нивен центар, каде што Турците се исклучиво бекташи, за разлика од Макриево и Бањско каде што се мешани, има бекташки и меламиски приврзаници. Филиповиќ додава дека бекташи се среќаваат и во селото Злеово (регион на Радовиш). За сите места во овој регион каде што се среќаваат бекташи, главното бекташко теќе се наоѓa во Штип (Filipović 1954: 10-13).

Еден значаен податок, кој сметам дека треба да се сподели, поврзан со тарикатскиот живот во Југославија е основањето на самостојната организација Сојуз на исламските дервишки редови на Алија (СИДРА) во 1974 година, со седиште во Призрен, како чадор-организација со цел унапредување на проучувањето и практикувањето на тасавуфот. Оваа организација започнала издавање на свое списание под наслов „ХУ“. Организацијата четири години подоцна го променила називот во ЗИДРА - Заедница на исламските дервишки редови на Алија во СФРЈ. Според пишувањето на списанието „ХУ“, во Југославија во 1978 година бројот на дервиши бил поголем од педесет илјади (Čolić 1995: 9).

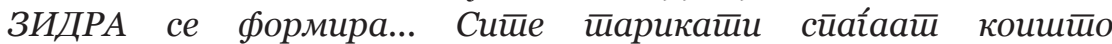

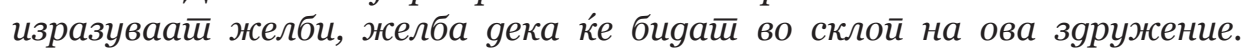

16 Сопствени теренски истражувања, 2019 година, западен дел на Македонија, мухип во бекташкиот тарикат на 67-годишна возраст.

17 Сопствени теренски истражувања, 2019 година, западен дел на Македонија, мухип во бекташкиот тарикат на 67-годишна возраст. 
Тука е шеј (x) Џемаљ, јас їо знам неїо. Се вияов со неі̄о, йој беше йрвиой иррейсеgайел на йаа, на йо зgружение... Шејх Џемаљ. Шејх Џемаљ-Шеху. Така е неїовойо иррезиме... На ниво на Југоославија. То е како мешихай,

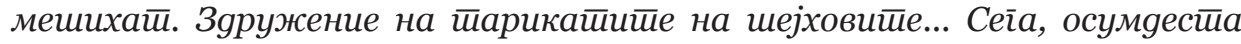
іоgина, оg сеgумgесей и осма іоgина можи gа е формирана. Og сеgумес осма, ишака мислам, ишака се сеќавам, оg ирилика некаgе. Сеgумgес осма мислам дека $\mathrm{e}^{18}$.

Оваа верска заедница СИДРА, односно ЗИДРА со своето дејствување навистина ќе придонесе за заживување, но во исто време и зачувување на тарикатскиот живот на просторите на Југославија, особено во последната деценија од социјалистичкиот период.

\section{Заклучни размислувања}

Преку овој труд се надевам дека успеав временски да го пренесам читателот во социјалистичкиот период во Македонија, но воедно да го запознам со приликите под кои бекташкиот дервишки ред егзистирал.

Од појавата на бекташкиот тарикат во Македонија до денес, постои еден континуитет во неговата егзистенција, секако со одредени осцилациии во различни периоди. Што се однесува до бекташиот тарикат во Македонија за време на социјализмот, одредени појави, прилики и процеси ќе бидат главни двигатели за неговите понатамошни текови.

За одбележување е „Договорот за слободна емиграција“, склучен помеѓу ФНР Југославија и Република Турција во 50-тите години на 20 век, кој бил судбоносен за тарикатскиот живот и теќињата во Македонија поради масовното иселување на муслиманската популација во Турција. Многу бекташки теќиња на подрачјето на Македонија се опустошени како резултат на преместувањето на населението.

Дел од оние бекташи што ја избегнале оваа „слободна емиграција“ и кои успеале да останат во Македонија и да ги зачуваат бекташките светилишта се соочиле со комунистичката власт, со нејзиниот поглед кон верското прашање, но и со одредени политички одлуки што директно влијаеле врз (не)функционирањето на одредени теќиња.

Во овој период се појавува една политичка одлука, односно е донесен Закон за национализација, кој ке има негативен ефект врз одредени теќиња. Едно од бекташките теќиња што било жртва на ваквата одлука, кога локалните власти решаваат да го узурпираат и да го претворат во туристички објект, е Харабати-баба теќето во Тетово.

Покрај Законот за национализација, друга политичка одлука во овој период што ќе влијае врз бекташкиот живот е носењето на Закон на Петгодишниот план за развој, кој ќе биде фатален за одредени бекташки светилишта.

18 Сопствено теренско истражување во Охрид, 2018 година. Соговорник Ејуп Салих, роден 22.9.1950 година во Охрид, муслиман, Турчин. 
Од друга страна пак, може да се каже дека власта во Македонија во социјалистичкиот период била потолерантна во однос на верското прашање во споредба со други соседни земји, бидејќи барем декларативно прокламирала дека теистичкиот или атеистичкиот поглед на светот е приватно право или лична слобода на секој поединец. Во одредени бекташки теќиња во Македонија без некои посериозни опструкции продолжил да се одвива бекташкиот тарикатски живот за време на социјализмот.

Во соседна Албанија, пак, со преземањето на власта од страна на комунистите во 1945 година, бекташкото влијание постепено ќе се намалува, а конечно, во 1967 година, кога Енвер Хоџа ги забранил сите верски практики во Албанија, бекташкиот тарикат ќе биде целосно парализиран.

Слична судбина доживеал и бекташкиот тарикат во Босна и Херцеговина кога во 1952 година тарикатските активности, вклучувајќи го и бекташкиот тарикат, во целост се забранети, не, како што би се помислило на прв поглед, од комунистичката власт, туку од модернистички настроената улема што раководела со Исламската заедница (под силно влијание на владејачките структури), кои братствата и шејховите ги сметале за заостанато архаично празноверие и внесување на новотарии (бидах) во верата. Сите теќиња во Босна и Херцеговина официјално се затворени.

Оваа забрана се одржала сѐ до седумдесеттите години на минатиот век, кога, благодарејќи најмногу на настојувањата на прочуените научници во муслиманската заедница кадири-мевлеви шејх и имам Фејзулах Хаџибајриќ (починал 1990) и рифајскиот шејх од Призрен Џемали Шеху, доаѓ до обновување на суфизмот во Југославија. Во 1974 година како самостојна организација е основан Сојуз на исламските дервишки редови на Алија (СИДРА), со седиште во Призрен, како чадор-организација со цел унапредување на проучувањето и практикувањето на тасавуфот. Оваа организација СИДРА, односно ЗИДРА со своето дејствување навистина ќе придонесе за заживување, но во исто време и зачувување на тарикатскиот живот на просторите на Југославија, особено во последната деценија од социјалистичкиот период.

\section{Извори}

ДАРМ, ф. Претседателство на Влада на НРМ, 159. 2. 53/241 - 247, Извештај за работата и организацијата на Верската комисија, 5. VII. 1945 година, цитирано во: Илиевски, Борче, Макеgонско-срӣскииее црковни оgноси 1944-1970, Институт за историја, Филозофски факултет, Скопје, 2011.

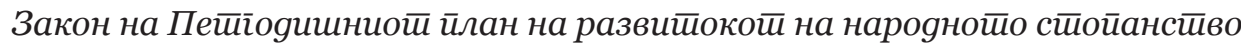
на Нароgна Рейублика Макеgонија во іоgиниие 1947 - 1951, Службен весник на Народна Република Македонија, бр. 24, год. III, Скопје, 1947 . 
Службен весник на ДФЈ, I/62, 21 август 1945 година, Уредба за основање Државна комисија за верски прашања, цитирано во: Илиевски, Борче, Макеgонско-сриескииее црковни оgноси 1944-1970, Институт за историја, Филозофски факултет, Скопје, 2011.

Службен весник на Р Македонија бр. 113 од 20.9.2007.

Novaković, Konstantin, Foto esej: Derviško proleće u Prizrenu, http://pescanik. net/foto-esej-dervisko-prolece-u-prizrenu/, пристапено на: 10.11.2019.

Tapu defteri No. 232, s 210a, Istanbul, Başbakanlık Arsivi, цитирано во: Петровски, Трајан. 1994. Дервишки ӣрсиен. Скопје: Култура.

The Path to Insight, http://bektashiorder.com/the-path-to-insight, пристапено на: 9.3.2015.

\section{Литература}

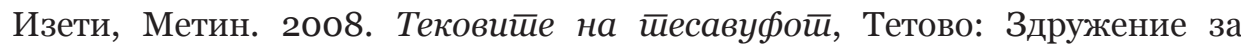
културна афирмација „СКОФИА“.

Илиевски, Борче. 2011. Макеgонско - срӣскийе црковни оgноси 1944-1970, Скопје: Институт за историја, Филозофски факултет.

Јордановска, Станислава. 2014. Празникой Ашуре кај gервишкиоӣ реg

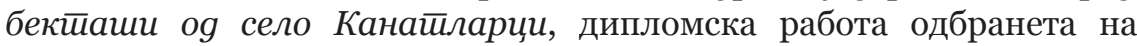
Институтот за етнологија и антропологија, Природно-математички факултет, ментор: проф. д-р Љупчо Ристески, Скопје, ракопис.

Конеска, Елизабета. 2006. „Дилеми околу историјата на црквата Св. Никола или X’д’р баба турбето во Македонски Брод“, Гласник 50 (1): 161 - 168.

Конеска, Елизабета. 2008. „Денот на ашуре кај тарикатите во Македонија“,

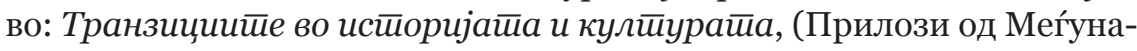
родната научна конференција одржана во Скопје на 30-31 октомври 2006 година, во соработка со Етнографскиот институт со музеј при Бугарската академија на науките), 421 -430. Скопје: Институт за национална историја. 
Конеска, Елизабета. 2009. „Преглед на бекташкиот дервишки ред во Р.

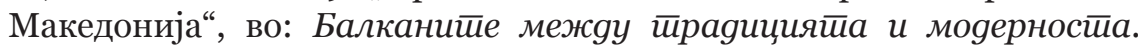

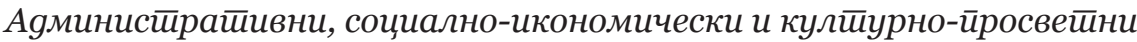

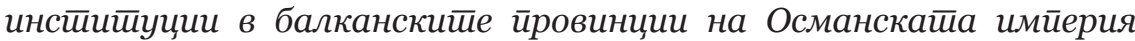
(XVIII-XIX век), 229 -255. София: ИК „ГУТЕНБЕРГ“.

Петровски, Трајан. 1994. Дервишки ӣрсиеен, Скопје: Култура.

Светиева Анета. 2000. „Социјална култура на четири Велешки села: Теово, Ореше, Мелница и Горно Врановци“, во проект The Multicultural and Ethnic Characteristics of Four Villages in the Veles Region - Republic of Macedonia, достапно на: http://www.ethnologs-dep.org/VELES/indexV. $\underline{\mathrm{htm}}$, пристапено на: 04.05.2014 г. веб-страната повеќе не е активна.

Стојановски, Александар. 1979. „Едно потврдено предание“, Музејски іласник на Исииорискиой музеј на Макеgонија 4: 53 - 57. Скопје.

Стојановски, Александар (редактор). 1998. „Македонија под турска власт (од XIV до крајот на XVIII век)“, во: Исӣорија на макеgонскиой нароg, том втори. Скопје: Институт за национална историја.

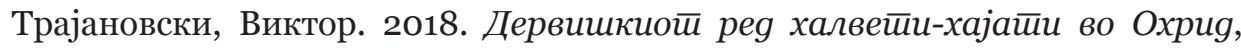
Скопје: Институт за етнологија и антропологија, Центар за етнолошки истражувања и применета антропологија.

Што е тоа Суфизам, достапно на: http://www.islamska-zaednica.com/forum/ topic/945-што-е-тоа-суфизам/, пристапено на: 12.12.2016.

Abiva, Hüseyin. A Glimpse at Sufism in the Balkans, https://www.alevibektasi.eu/index.php?option $=$ com $\quad$ content\&view $=$ article \&id $=689 \% 3 \mathrm{Aa}-$ glimpse-at-sufism-in-the-balkans \&catid $=46 \% 3$ Aaratrmalaringilizce\&Itemid=69, пристапено на: 28.8.2018.

Birge, John Kingsley. 1937. The Bektashi Order of Dervishes, Luzac \& CO., London W.C.

Ćehajić, Džemal. 1986. Derviški redovi u jugoslovenskim zemljama sa posebnim osvrtom na Bosnu i Hercegovinu, Sarajevo: Grafo-art atelje.

Čolić, Ljiljana. 1995. Derviški redovi muslimanski: Tekije u Skoplju, knjiga LXXIV. Beograd: Filološki fakultet u Beogradu. 
Filipović, Milenko S. 1954. „The Bektashi in the District of Strumica (Macedonia)", Man 54: 10-13.

Hasluck, Frederick William. 1929. Christianity and Islam under the Sultans, Vol. II. Oxford: Clarendon Press.

Izeti, Metin. 2001. Tarikatı Bektashian, Tetovë:,Çabej“.

Kara, Mustafa, Din Hayat Sanat Açısından Tekkeler ve Zaviyeler, Istanbul 1999,

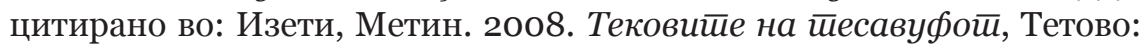
Здружение за културна афирмација „СКОФИА“. 
ЕтноАнтропоЗум 